\title{
EKSTRAKSI ZAT WARNA DARI DAUN JATI MUDA (Tectona grandis Linn. F.) DAN APLIKASINYA PADA BENANG TENUNAN BIMA
}

\author{
Silaturahmi ${ }^{1}$, Agrippina Wiraningtyas ${ }^{1}$, Ruslan $^{1}$ \\ ${ }^{1}$ Program Studi Pendidikan Kimia STKIP BIMA \\ E-mail :Silaturahmi25@gmail.com
}

\begin{abstract}
ABSTRAK
Indonesia adalah negara yang sangat kuat dalam penyediaan bahan baku bersumber dari alam, namun masyarakat belum mampu memanfaatkannya dengan baik. Salah satu tumbuhan yang dapat berpotensi sebagai pewarna alami adalah daun jati muda (Tectona grandis Linn. F.). Dimana daun jati muda mengandung zat pewarna antosianin yang dapat memberikan warna merah, ungu bahkan merah gelap dan tanin yang dapat memberikan warna cokelat. Tujuan penelitian ini adalah mengetahui pengaruh konsentrasi pelarut terhadap ekstrak zat warna pada daun jati muda, mengetahui konsentrasi optimum pada ekstraksi zat warna dari daun jati muda dengan menggunakan metode maserasi dan mengetahui pengaruh variasi konsentrasi pelarut terhadap zat warna daun jati muda pada pewarnaan benang bahan baku kain tenunan Bima. Ekstrak daun jati muda didapat dengan cara diekstraksi menggunakan metode maserasi dengan pelarut etanol konsentrasi 50\%, 60\%, 70\%, 80\% dan 90\%. Ekstrak yang diperoleh kemudian diukur nilai absorbansinya menggunakan alat spektrofotometer Uv-Vis pada rentang panjang gelombang 190-700 nm, serta digunakan untuk mewarnai benang tenunan. Hasil penelitian ini adalah variasi konsentrasi pelarut etanol berpengaruh terhadap ekstrak zat warna dari daun jati muda dengan metode maserasi. Konsentrasi optimum pelarut etanol untuk ekstraksi zat warna dari daun jati muda dengan metode maserasi adalah konsentrasi pelarut etanol $80 \%$ yang menghasilkan nilai absorbansi 1,425. Dan variasi konsentrasi pelarut etanol berpengaruh terhadap hasil warna pada bahan baku benang tenunan Bima.
\end{abstract}

Kata Kunci: Ekstraksi, Maserasi, Daun Jati Muda, Zat Warna, Benang Tenunan.

\section{PENDAHULUAN}

Indonesia merupakan negara yang sangat kuat dalam penyediaan bahan baku bersumber dari alam. Namun belakangan industri tekstil yang menggunakan pewarna sintetis sebagai pengganti zat warna alam, karena dirasa lebih ekonomis, praktis, dan mudah didapatkan. Penggunaan zat warna sintetis untuk bahan tekstil telah banyak menimbulkan masalah lingkungan karena konsumen karena dapat menyebabkan kanker kulit, kanker mulut, kerusakan otak, serta menimbulkan dampak bagi lingkungan seperti pencemaran air dan tanah yang juga berdampak secara tidak langsung bagi kesehatan manusia dan di dalamnya terkandung unsur logam berat seperti Timbal ( $\mathrm{Pb}$ ), Tembaga ( $\mathrm{Cu})$, Seng ( $\mathrm{Zn}$ ) yang berbahaya (Wiraningtyas, 2019). Sehingga perlunya dilakukan penelitian dan inovasi pemanfaatan bahan alam sebagai pewarna alami. Salah satu tumbuhan yang dapat berpotensi sebagai pewarna alami adalah daun jati (Tectona grandis Linn. F.). Daun jati mengandung zat pewarna antosianin yang dapat memberikan warna merah, ungu bahkan merah gelap (Mutmainnah, 2018) dan tanin yang dapat memberikan warna cokelat.

Berdasarkan hasil observasi, daun jati muda yang jumlahnya berlimpah belum mampu dimanfaatkan dengan baik oleh masyarakat di daerah pegunungan. Padahal, jika dilihat dari kandungan senyawa aktif didalamnya, daun jati muda dapat dimanfaatkan untuk menghasilkan zat warna alami. Ekstrak zat warna dari daun jati muda dapat dihasilkan dengan jalan ekstraksi (Kristiana, 2012).

Ekstraksi adalah suatu metode yang dapat mengeluarkan komponen tertentu dari zat padat atau zat cair dengan cara pelarutan (Mastuti, dkk., 2013). Metode yang digunakan 
dalam penelitian ini adalah metode maserasi. Keuntungan menggunakan metode ini yaitu lebih sederhana dengan teknik merendam bahan selama beberapa hari atau beberapa jam dengan pelarut yang sesuai. Faktor-faktor yang berpengaruh pada proses ekstraksi, antara lain: jenis pelarut, ukuran bahan padat yang diekstraksi, suhu, waktu dan yang paling berpengaruh adalah konsentrasi. Pelarut yang digunakan dalam penelitian ini untuk memperoleh senyawa zat warna adalah etanol. Zat warna yang dihasilkan tersebut bisa dimanfaatkan sebagai pewarna alami salah satunya sebagai pewarna benang tenunan. Tenun merupakan kain tradisional Indonesia yang diproduksi di berbagai wilayah Nusantara seperti Sumatera, Kalimantan, Bali, Sulawesi, Lombok, Sumbawa, dan Bima. Tenun yang dihasilkan dari berbagai daerah memiliki motif yang berbeda-beda, serta memiliki makna dan nilai sejarah yang tidak sama dengan teknik tenun yang berbeda. Hal ini terlihat dari segi warna, ragam hias dan jenis bahan serta benang yang digunakan.

Berdasarkan latar belakang di atas, maka pada penelitian ini akan dilakukan ekstraksi zat warna dari daun jati muda dan aplikasinya pada benang tenunan Bima dengan metode maserasi. Pelarut yang digunakan dalam penelitian ini yaitu etanol dengan variasi konsentrasi yang diteliti adalah 50\%, 60\%, 70\%, 80\% dan 90\%. Konsentrasi optimum pelarut etanol dapat ditentukan dengan mengukur absorbansi ekstrak zat warna hasil ekstraksi menggunakan spektrofotometer UV-Vis pada panjang gelombang 500-700 nm (Mutmainnah, 2018).

\section{METODE}

\section{Alat dan Bahan}

Adapun alat yang diperlukan dalam penelitian ini adalah Baskom, blender (penghalus), sendok, gelas ukur, labu ukur ukuran $100 \mathrm{~mL}$, pipet volum, tabung reaksi, rak tabung reaksi, neraca analitik, gunting, batang pengaduk, beker, corong, labu erlenmeyer, Thermometer, kompor, toples, mangkuk kaca dan Spektrofotometer UV-Vis. Sedangkan bahan yang diperlukan dalam penelitian ini adalah daun jati muda (Tectona grandis Linn. F.), aquades, etanol $96 \%$, kertas saring, kertas label, plastik, kapur tohor $\left(\mathrm{CaCO}_{3}\right)$, tawas, tunjung $\left(\mathrm{FeSO}_{4}\right)$, dan soda abu $\left(\mathrm{Na}_{2} \mathrm{CO}_{3}\right)$.

\section{Prosedur Penelitian}

Prosedur penelitian ini dilakukan melalui beberapa tahap kegiatan sebagai berikut:

\section{Persiapan Sampel:}

Sampel diambil dari gunung kelurahan Nitu, Kecamatan Raba, Kota Bima berupa daun jati muda, dalam keadaan masih segar. Daun jati muda yang masih segar dibersihkan dengan cara dicuci untuk menghilangkan benda asing yang menempel, lalu dipotong kecil-kecil, kemudian ditumbuk/diblender agar memiliki luas permukaan yang lebih besar.

\section{Pembuatan Pelarut Etanol Berbagai Konsentrasi}

Pada penelitian ini digunakan pelarut etanol masing-masing $100 \mathrm{~mL}$ dengan variasi konsentrasi $50 \%, 60 \%$, 70\%, $80 \%$ dan $90 \%$. Etanol yang tersedia dalam konsentrasi $96 \%$, jadi akan diencerkan terlebih dahulu dengan aquades.

\section{Tahap Ekstraksi Zat Warna dari Daun Jati Muda dengan Variasi Konsentrasi Pelarut Etanol}

Sampel daun jati muda yang akan diekstrak ditimbang sebanyak 50 gram. Kemudian dimasukkan ke dalam mangkuk kaca masing-masing 10 gram lalu ditambahkan 
masing-masing $100 \mathrm{~mL}$ pelarut etanol dengan variasi konsentrasi $50 \%, 60 \%, 70 \%, 80 \%$ dan $90 \%$. Pelarut dan zat terlarut ini diekstraksi dengan metode maserasi pada suhu ruang dengan lama waktu maserasi 3 jam. Sehingga didapatkan 5 larutan dengan variasi konsentrasi yang berbeda-beda. Setelah ekstrak tercampur dengan waktu maserasi yang ditentukan pelarut disaring menggunakan kertas saring. Hasil penyaringan berupa residu dan filtrat. Pada penelitian filtrat yang akan dimanfaatkan untuk tahap berikutnya. Tahap selanjutnya dilakukan uji yaitu uji fisik dilihat dengan melihat langsung warna hasil ekstrak. Sedangkan untuk uji kimia yaitu pengujian menggunakan spektrofotometer UV-Vis dengan panjang gelombang $500-700 \mathrm{~nm}$.

\section{Tahap Pewarnaan Benang Bahan Baku Kain Tenunan Bima Dari Hasil Ekstraksi Zat Warna Pada Daun Jati Muda \\ Tahap Mordanting}

Siapkan benang, tawas dan soda abu, timbang tawas sebanyak 12 gr untuk 2 liter air, kemudian timbang soda abu sebanyak 4 gram untuk 2 liter air. Setelah itu untuk proses perebusan mula-mula larutkan tawas dengan 1 liter air, setelah tawas larut dalam air, kemudian ditambah kekurangan airnya sebanyak 1 liter air. Lalu setelah mencapai suhu 60 ${ }^{\circ} \mathrm{C}$ tambahkan soda abu dan 2 liter air, aduk dan tunggu soda abu tercampur dengan air. Setelah semua sudah tercampur, kecilkan api dan masukkan benang pada larutan dengan posisi suhu stabil $60{ }^{\circ} \mathrm{C}$ dan tunggu hingga \pm 1 jam. Setelah itu matikan kompor dan biarkan benang pada rendaman selama semalam. Keesokan harinya baru ditiriskan, dibilas bersih dan dijemur sampai kering.

\section{Tahap Pewarnaan Benang}

Rendam benang pada zat warna dengan 5 variasi konsentrasi selama 15 menit, angkat dan jemur benang hingga kering.

\section{Tahap Fiksasi}

Siapkan larutan fiksator tawas, tunjung dan kapur tohor, rendam benang \pm 2 menit, benang dibolak-balik agar merata, setelah 2 menit angkat benang, peras dan jemur hingga kering.Tahap selanjutnya dilakukan uji, yaitu uji fisik dengan melihat langsung warna yang dihasilkan pada benang.

\section{HASIL DAN PEMBAHASAN}

Hasil

\section{Hasil Ekstraksi Zat Warna dari Daun Jati Muda (Tectona grandis Linn. F.) dengan Metode Maserasi Variasi Konsentrasi Pelarut Etanol Data Uji Fisik}

Pada data uji fisik didapatkan hasil berupa ekstrak berwarna merah, merah kecokelatan dan merah kehitaman. Berikut warna secara fisik ekstrak zat warna dari daun jati muda pada konsentrasi pelarut 50\%,60\%, 70\%, 80\% dan 90\%.

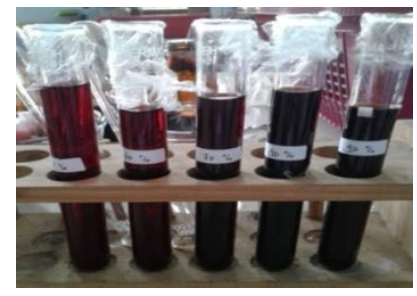

Gambar 1. Ekstrak daun jati muda dengan variasi konsentrasi pelarut 


\section{Data Absorbansi Ekstrak}

Pada data absorbansi ekstrak didapatkan nilai absorbansi sebagai berikut:

Tabel 1. Data Nilai Absorbansi Tertinggi Variasi Konsentrasi Pelarut Etanol

\begin{tabular}{|c|c|c|}
\hline Nomor & $\begin{array}{c}\text { Konsentrasi } \\
\text { Pelarut Etanol }\end{array}$ & $\begin{array}{c}\text { Nilai Absorbansi pada } \lambda \text { maks } \\
205 \mathrm{~nm}\end{array}$ \\
\hline 1. & $50 \%$ & $1,272^{\mathrm{c}}$ \\
2. & $60 \%$ & $1,188^{\mathrm{d}}$ \\
3. & $70 \%$ & $1,163^{\mathrm{e}}$ \\
4. & $80 \%$ & $1,425^{\mathrm{a}}$ \\
5. & $90 \%$ & $1,361^{\mathrm{b}}$ \\
\hline
\end{tabular}

Hasil Pewarnaan Benang Bahan Baku Kain Tenunan Bima dengan Zat Warna Daun Jati Muda Variasi Konsentrasi Pelarut Etanol

Dari hasil penelitian dapat diketahui bahwa daun jati muda dapat mewarnai benang tenunan Bima dengan warna ungu, karena daun jati muda mengandung senyawa antosianin. Senyawa antosianin adalah senyawa yang dapat memberikan warna merah, ungu dan merah gelap (Mutmainnah, 2018). Berikut warna secara fisik benang hasil pewarnaan menggunakan zat warna dari daun jati muda dengan konsentrasi pelarut etanol $50 \%, 60 \%, 70 \%$, $80 \%$ dan $90 \%$.

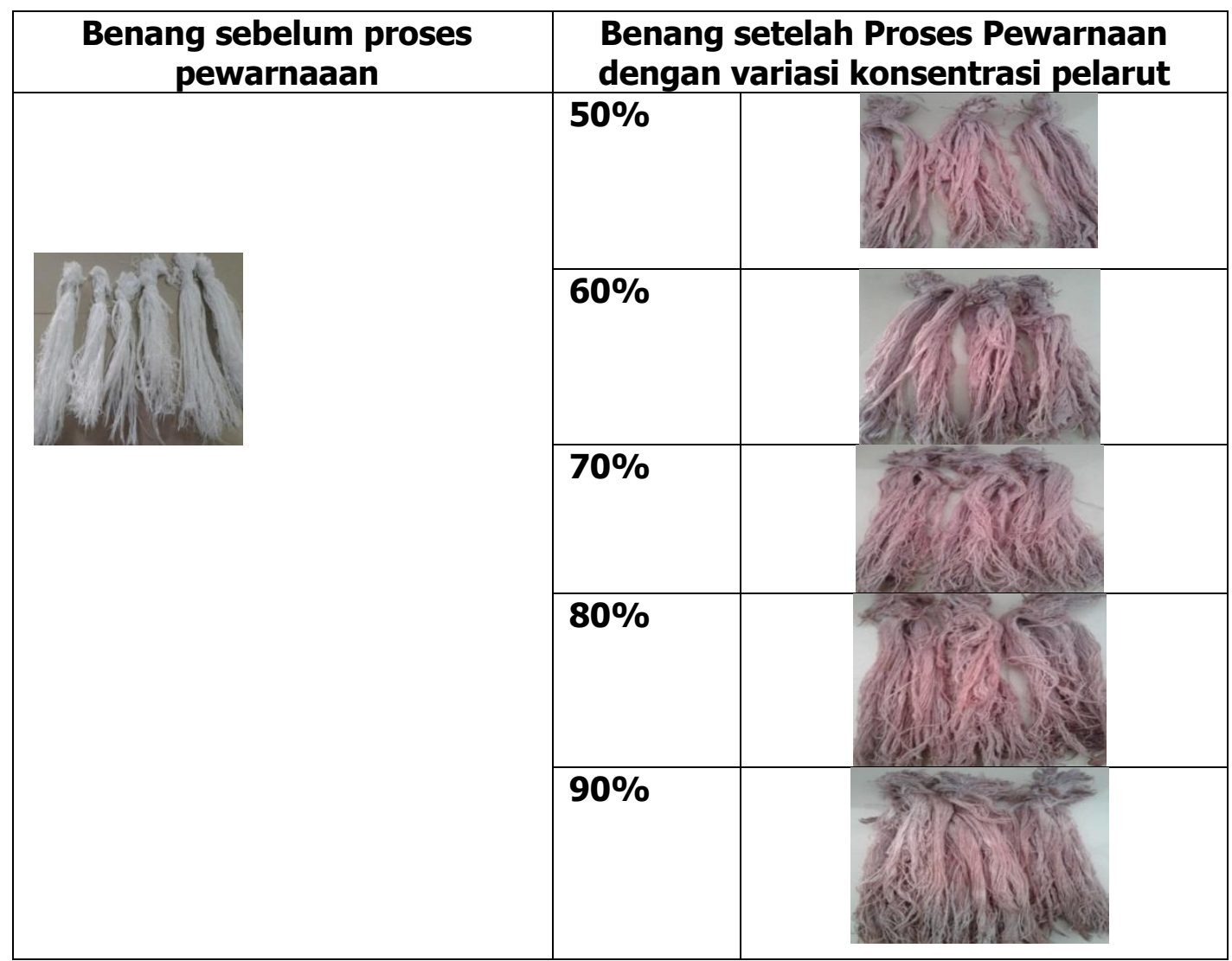

Gambar 2. Hasil warna benang setelah proses pewarnaan dengan ekstrak daun jati muda

\section{Pembahasan}

\section{Ekstraksi Zat Warna dari Daun Jati Muda (Tectona grandis Linn. F.)} Tahap Preparasi Sampel

Tujuan dari preparasi sampel yaitu untuk mendapatkan serbuk daun jati muda, sehingga perlu perlakuan yang diawali dengan pencucian untuk menghilangkan benda 
asing yang menempel agar tidak mengganggu ekstrak yang dihasilkan. Selanjutnya, sampel dikeringkan pada suhu ruang tanpa terkena oleh cahaya matahari secara langsung karena akan merusak metabolit sekunder yang terkandung pada daun jati muda (Mutmainnah, 2018). Kemudian sampel dipotong kecil-kecil dan dihaluskan untuk menghasilkan serbuk sehingga mempermudah penarikan zat-zat aktif pada saat perendaman (maserasi). Serbuk yang diperoleh berwarna cokelat dan disimpan pada wadah yang kering, bersih dan terhindar dari cahaya matahari untuk mencegah kerusakan.

\section{Ekstraksi dengan Berbagai Variasi Konsentrasi Pelarut}

Ekstraksi dilakukan dengan memvariasikan konsentrasi pelarut untuk mengetahui pengaruh konsentrasi dan konsentrasi maksimum, sehingga perlakuan dimulai dari serbuk daun jati muda ditimbang sebanyak 50 gram, dimasukan kedalam mangkuk kaca dengan masing-masing 10 gram serbuk daun jati muda dan dimaserasi selama 3 jam menggunakan pelarut etanol variasi konsentrasi $50 \%, 60 \%, 70 \%, 80 \%$ dan $90 \%$ dari hasil pengenceran etanol $96 \%$ dengan aquades. Variasi konsentrasi pelarut etanol tersebut diadaptasi dari penelitian sejenis yang dilakukan oleh Putri dkk. (2018) yang menyatakan bahwa, variasi konsentrasi pelarut etanol pada senyawa brazilin menghasilkan senyawa brazilin tertinggi pada konsentrasi etanol $90 \%$ dengan rata-rata absorbansi yaitu 0,555.

Metode maserasi dipilih karena metode ini dapat menghasilkan ekstrak dengan flavor yang baik dan dilakukan tanpa melalui proses pemanasan sehingga dapat mengurangi kerusakan komponen aromatik (Wiraningtyas, dkk., 2019). Untuk dapat mengetahui dan mengukur hasil ekstraksi zat warna dari daun jati muda dilakukan dengan dua uji, yaitu uji fisik dan uji kimia.

Pada uji fisik dengan pengamatan secara langsung didapatkan hasil warna ekstrak yaitu warna merah untuk konsentrasi pelarut 50\%, 60\% dan 70\%, warna merah kecokelatan untuk konsentrasi pelarut $80 \%$ dan warna merah kehitaman untuk konsentrasi pelarut $90 \%$. Hasil uji fisik dapat dilihat pada gambar 4.2 di atas, pada gambar 4.2 terlihat semakin tinggi konsentrasi pelarut etanol maka ekstrak yang dihasilkan semakin pekat warnanya. Dapat disimpulkan bahwa variasi konsentrasi pelarut etanol berpengaruh terhadap hasil ekstrak zat warna dari daun jati muda dengan menggunakan metode maserasi. Hal ini sesuai dengan penelitian yang dilakukan oleh Diantika, dkk. (2014), yang menyatakan bahwa variasi konsentrasi pelarut etanol memberikan pengaruh terhadap ekstrak biji kakao yang dihasilkan dari proses ekstraksi.

Sedangkan pada analisis yang dilakukan dengan uji kimia menggunakan alat spektrofotometer UV-Vis sampel harus diencerkan terlebih dahulu dengan pengenceran sebanyak seratus kali. Sebelum pengukuran, harus dicari rentang panjang gelombang untuk dapat mengukur nilai absorbansi, dalam teori range panjang gelombang untuk pengukuran sampel daun jati muda yaitu 500-700 nm (Mutmainnah, 2018). Namun, ketika rentang panjang gelombang tersebut digunakan untuk mengukur hasil ekstrak ternyata sampel tidak terukur absorbansinya, sehingga rentang panjang gelombang diatur menjadi 190-700 nm. Rentang panjang gelombang 190-700 nm dipilih agar sampel dapat terbaca oleh sinar UV, dimana senyawa organik dapat menyerap sinar UV pada panjang gelombang antara 100-700 nm. Namun, dalam penelitian ini batas bawah (minimum) panjang gelombang yang dipilih adalah $190 \mathrm{~nm}$ bukan $100 \mathrm{~nm}$, karena batas bawah panjang gelombang yang dapat terbaca oleh double-beam instrument adalah $190 \mathrm{~nm}$. Sedangkan, batas atas (maksimum) pada rentang panjang gelombang tersebut dipilih $700 \mathrm{~nm}$, karena 
pada panjang gelombang $700 \mathrm{~nm}$ adalah batas maksimum senyawa organik dapat menyerap sinar UV agar absorbansinya dapat terbaca (Awaliyah, 2018). Berdasarkan hal tersebut, maka rentang panjang gelombang dalam penelitian ini dipilih antara 190-700 nm. Nilai absorbansi yang diperoleh dapat dilihat pada tabel 4.3 di atas.

Selanjutnya dilakukan penentuan panjang gelombang maksimum ( $\lambda$ maks). Berdasarkan hasil pengukuran dengan menggunakan spektrofotometer UV-Vis maka didapatkan panjang gelombang maksimum ( $\lambda$ maks) untuk pengukuran hasil ekstraksi adalah sebesar $205 \mathrm{~nm}$ dengan absorbansi sebesar 1,425. Oleh karena itu, panjang gelombang $205 \mathrm{~nm}$ dipilih sebagai panjang gelombang maksimum ( $\lambda$ maks) untuk pengukuran hasil ekstrak zat warna dari daun jati muda (Tectona grandis Linn. F.) dengan metode maserasi variasi konsentrasi pelarut etanol. Berikut adalah diagram garis hubungan absorbansi dengan ekstrak zat warna dengan konsentrasi pelarut etanol.

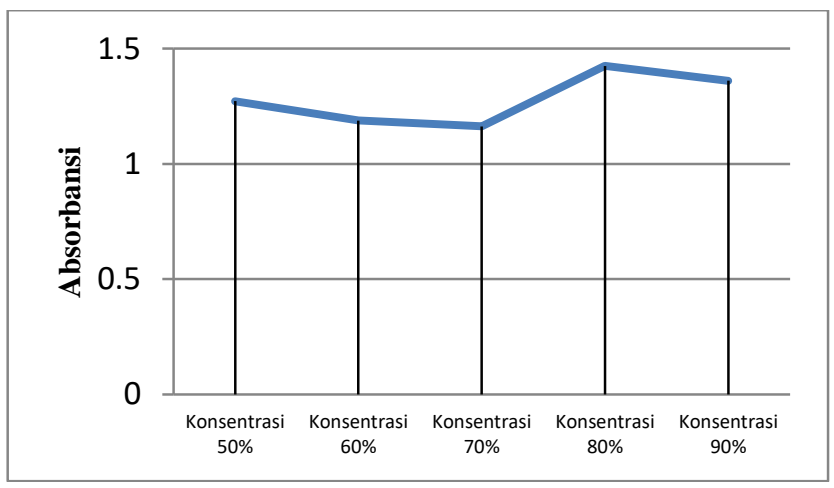

Gambar 3. Grafik UV Vis ekstrak zat warna daun jati muda pada berbagai konsentrasi pelarut

Berdasarkan perhitungan nilai indeks polaritas menurut Swantara (2014), pelarut etanol konsentrasi $50 \%$, 60\% dan $70 \%$ memiliki nilai indeks polaritas 7,02; 6,62 dan 6,23 yang menghasilkan ekstrak zat warna merah dengan nilai absorbansi 1,$272 ; 1,188$ dan 1,163 berturut-turut untuk konsentrasi pelarut 50\%, 60\% dan $70 \%$. Terjadinya penurunan nilai absorbansi dari 1,272 menjadi 1,163 disebabkan karena semakin berkurangnya kadar zat warna antosianin yang teresktrak. Berkurangnya kadar antosianin yang terekstrak disebabkan penurunan nilai indeks kepolaran dari pelarut etanol, walaupun ketiga konsentrasi pelarut ini masih bersifat polar. Semakin polar pelarut etanol maka semakin banyak kadar antosianin yang terekstrak karena antosianin juga bersifat polar. Suatu senyawa akan semakin larut dalam pelarut yang memiliki sifat kepolarannya sama.

Selanjutnya pada pelarut etanol konsentrasi $80 \%$ hasil ekstrak yang dihasilkan adalah yang terbanyak (paling pekat) dibandingkan dengan konsentrasi lain. Hal tersebut ditunjukkan dengan nilai absorbansi yang didapatkan adalah yang tertinggi yaitu 1,425 . Nilai indeks polaritasnya adalah 5,83, terjadi penurunan kepolaran. Nilai indeks polaritas pelarut etanol konsentrasi $80 \%$ cocok digunakan untuk mengekstraksi zat warna dalam daun jati muda. Hal ini dikarenakan sifat kepolaran dari pelarut etanol konsentrasi $80 \%$ adalah semi polar, sehingga mampu mengekstrak senyawa antosianin dan tanin sekaligus, dengan warna yang dihasilkan adalah warna merah kecokelatan. Warna merah dari antosianin dan warna cokelat dari tanin. Hal ini yang menyebabkan terjadinya peningkatan nilai absorbansi 
pada konsentrasi pelarut $80 \%$. Karena semakin banyak zat yang diekstrak maka semakin tinggi nilai absorbansinya.

Kemudian, ekstraksi dilakukan dengan menggunakan pelarut etanol konsentrasi $90 \%$. Pelarut etanol konsentrasi $90 \%$ memiliki nilai indeks polaritas 5,42 . Sifat kepolaran pelarut ini semakin mengarah ke non polar. Sehingga antosianin dan tanin yang terekstrak semakin menurun kadarnya seiring dengan penurunan nilai indeks polaritas. Hal inilah yang menyebabkan terjadinya penurunan nilai absorbansi hasil ekstrak menjadi 1,361 pada konsentrasi pelarut $90 \%$ dan warna yang dihasilkan adalah merah kehitaman.

\section{Pewarnaan Benang Bahan Baku Kain Tenunan Bima dengan Zat Warna Daun Jati Muda Variasi Konsentrasi Pelarut Etanol Tahap Mordanting}

Tahap mordanting bertujuan untuk mensterilkan benang dari unsur logam dan lemak, mengembangkan serat benang sehingga mudah diserap zat warna alam (Lestari, dkk., 2018). Benang yang digunakan adalah benang berwarna putih dengan massa masing-masing 7,5 gram untuk setiap konsentrasi pelarut. Hasil benang dari proses mordanting dapat dilihat dalam gambar 4. berikut:

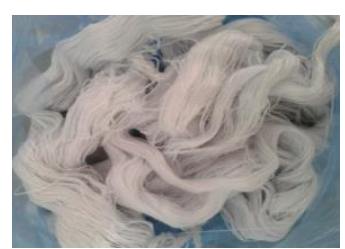

Gambar 4.a. Benang sebelum dimordanting

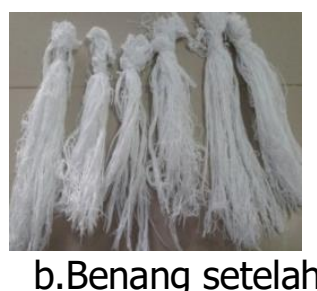

dimordanting

\section{Tahap Pewarnaan Benang}

Pewarnaan benang menggunakan bahan alamberupa daun jati muda yaitu dengan cara benang direndam ke dalam ekstrak daun jati muda selama 15 menit. Tujuan dari proses perendaman ini agar terjadi penyerapan zat warna ke dalam benang (Azizah, 2018). Hasil pewarnaan benang dapat dilihat pada tabel 4.4. Berdasarkan tabel 4.4 di atas dapat dilihat perubahan warna yang dihasilkan, benang yang awalnya berwarna putih tetapi mengalami perubahan warna setelah direndam dalam zat warna ekstrak daun jati muda. Warna yang dihasilkan yaitu untuk konsentrasi pelarut $50 \%$ menghasilkan warna violet, konsentrasi $60 \%$ warna plum, konsentrasi $70 \%$ warna orchid, konsentrasi $80 \%$ warna darkmagenta dan konsentrasi $90 \%$ warna ungu. Dapat disimpulkan, warna semua benang dengan pewarnaan menggunakan ekstrak daun jati muda yaitu warna ungu, karena semua warna yang dihasilkan pada benang tersebut adalah turunan dari warna ungu.

\section{Tahap Fiksasi}

Pada proses akhir pewarnaan dengan zat warna alam dilakukan proses fiksasi. Tujuannya yaitu untuk penguncian warna, agar warna memiliki ketahanan luntur yang baik (Thomas, dkk., 2013). Berikut adalah tabel hasil warna benang menggunakan pewarna ekstrak daun jati muda dengan variasi konsentrasi pelarut etanol setelah proses fiksasi. 


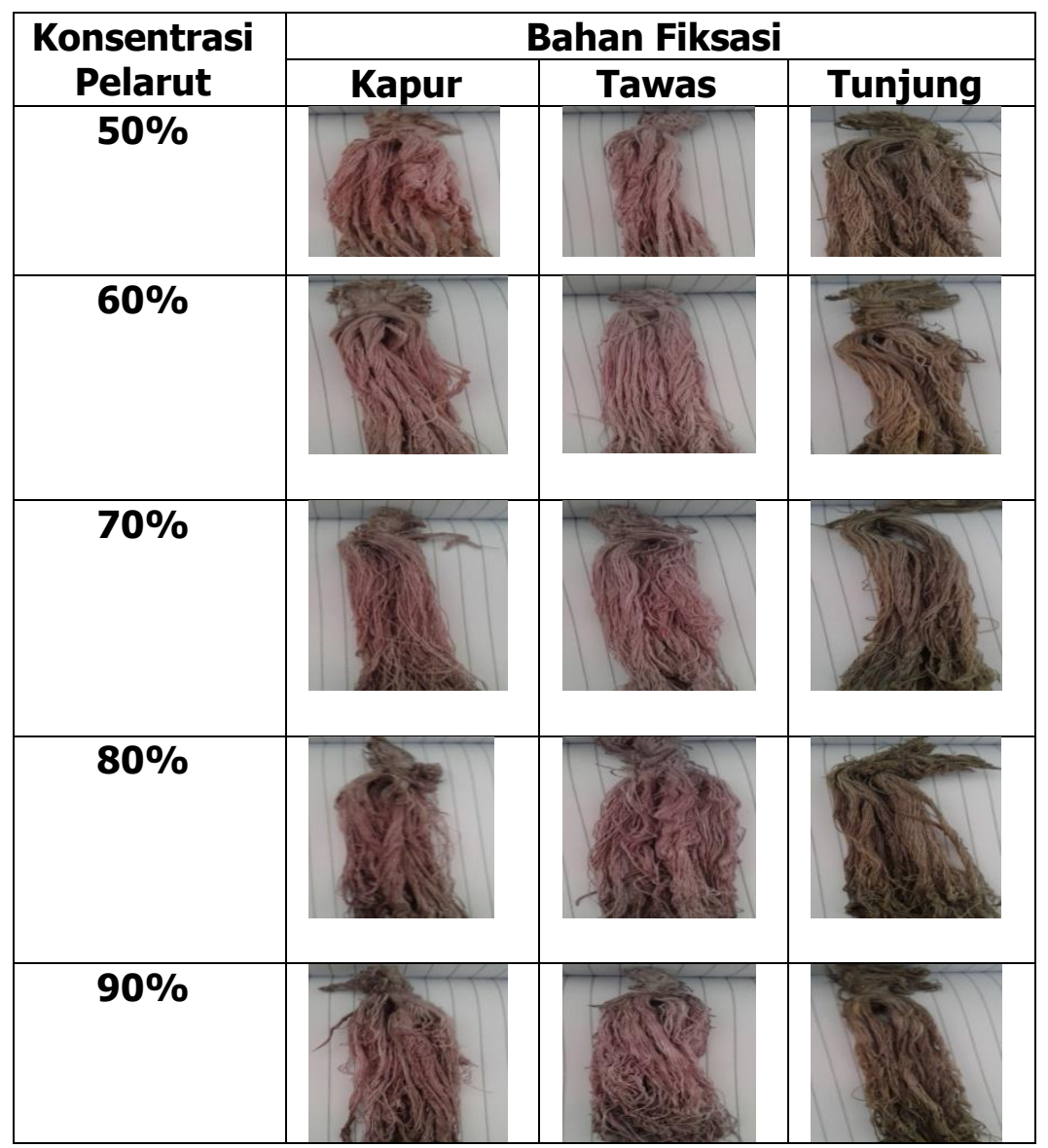

Gambar 5. Produk benang setelah difiksasi

Berdasarkan gambar 5. dapat dilihat adanya perbedaan warna benang dari pewarnaan menggunakan ekstrak daun jati muda (Tectona grandis Linn. F.) dengan berbagai variasi konsentrasi pelarut etanol. Warna awal benang sebelum difiksasi yaitu untuk konsentrasi pelarut $50 \%$ adalah warna violet, konsentrasi $60 \%$ warna plum, konsentrasi $70 \%$ warna orchid, konsentrasi $80 \%$ warna darkmagenta dan konsentrasi $90 \%$ warna ungu. Namun setelah difiksasi menggunakan tawas, kapur dan tunjung terjadi perubahan warna pada benang menjadi warna thistle untuk benang yang menggunakan bahan fiksasi kapur dan tawas dengan konsentrasi pelarut 50\%, 60\% dan 70\%. Sedangkan dengan konsentrasi pelarut $80 \%$ dan $90 \%$ warna benang menjadi warna plum. Perubahan warna yang terjadi pada benang dengan bahan fiksasi tawas dipengaruhi oleh senyawa kimia yang terdapat dalam tawas yaitu $\mathrm{Al}^{3+}$ yang bereaksi dengan ekstrak daun jati muda sedangkan untuk bahan fiksasi kapur dipengaruhi oleh kandungan senyawa yang terdapat dalam kapur yaitu $\mathrm{Ca}^{2+}$ yang bereaksi dengan ekstrak daun jati muda (Septiandini \& Muflihati, 2019). Kemudian yang menggunakan bahan fiksasi tunjung dengan konsentrasi pelarut $50 \%, 60 \%, 70 \%, 80 \%$ dan $90 \%$ warna benang yang dihasilkan yaitu warna abuabu. Itu disebabkan kandungan besi yang terdapat dalam tunjung dan adanya proses oksidasi membuat warna yang dihasilkan pada benang menjadi tua (Fardhyanti dan Ria, 2015). Hal ini juga terjadi pada penelitian yang dilakukan oleh Azizah (2018) dimana warna kain mori primissima dengan bahan fiksasi tawas dan kapur menghasilkan hasil yang lebih baik, karna warna yang dihasilkan lebih terang dibandingkan dengan hasil yang didapatkan dari bahan fiksasi tunjung. 


\section{KESIMPULAN}

Berdasarkan hasil penelitian dapat disimpulkan bahwa variasi konsentrasi pelarut etanol berpengaruh terhadap ekstrak zat warna dari daun jati muda dengan konsentrasi optimum pelarut etanol adalah konsentrasi pelarut etanol $80 \%$ yang menghasilkan nilai absorbansi 1,425 . Serta variasi konsentrasi pelarut etanol berpengaruh terhadap hasil warna pada bahan baku benang tenunan Bima.

\section{DAFTAR PUSTAKA}

Awaliyah, N. S. (2018). Ekstraksi Zat Warna dari Runput Laut Sargassum sp. dengan Metode Refluks. Bima: Sekolah Tinggi Keguruan dan Ilmu Pendidikan (STKIP) Bima.

Azizah, Wahidatun, N. (2018). Pengaruh Jenis Zat Fiksasi Terhadap Kualitas Pewarnaan Kain Mori Primissima dengan Zat Warna Euphorbia. Yogyakarta: Universitas Negeri Yogyakarta.

Diantika, F., Sutan, S. M., \& Yulianingsih, R. (2014). Pengaruh Lama Ekstraksi dan Konsentrasi Pelarut Etanol Terhadap Ekstraksi Antioksidan Biji Kakao (Theobroma cacao L.) Effect of Long Extraction and Concentration and Concentration of Ethanol Solvent Extraction Antioxidant Cocoa Beans (Theobroma cacao L.). Jurnal Teknologi Pertanian, 15 (3):159-164.

Fardyanti, D. S. \& Ria, D. R. (2015). Pemungutan Brazilin dari Kayu Secang (Caesalpinia Sappan L) dengan Metode Maserasi dan Aplikasinya untuk Pewarnaan Kain. Jurnal Bahan Alam Terbarukan, 4 (1):6-13.

Kristiana, H. D., Setyaningrum, A., \& Lia, U. K. (2012). Ekstraksi Pigmen Antosianin Buah Senggani (Melastoma Malabathricum Auct. Non Linn) dengan Variasi Jenis Pelarut. Jurnal Teknosains Pangan,1 (1):105-109.

Lestari, A. A., Evy, W., \& Yeni, M. (2018). Pemanfaatan Tumbuhan Penghasil Warna Alami Untuk Tenun Ikat Oleh Suku Dayak Iban Di Dusun Tekalong dan Dusun Kelawik Kapuas Hulu Kalimantan Barat. Jurnal Hutan Lestari, 6 (4):837-847

Mastuti, E., Winaputri, M. G., \& Harlyandi, P. (2013). Ekstraksi Zat Warna Alami Kelopak Bunga Rosella dengan Pelarut Etanol. Ekuilibrium, 12 (2):49-53.

Mutmainnah, Dian. (2018). Ekstraksi dan Uji Stabilitas Zat Warna Alami dari Daun Jati (tectona grandis linn.f.) Sebagai Bahan Pengganti Pewarna Sintetik Pada Produk Minuman. Makasar: Universitas Islam Negeri Alauddin Makassar.

Putri, U. S., Ana, H. M., \& Ayu, R. S. (2018). Pengaruh Konsentrasi Pelarut Etanol Terhadap Absorbansi Brazilin pada Simplisia Kayu Secang (Caesalppinia sappan L.). Semarang. Seminar Nasional Mahasiswa Unismu.

Septiandini, T. N., \& Muflihati. (2019). Ekstrak Buah Bakau Rhizophora mucronata Lamk Sebagai Pewarna Alami Pada Kain Katun. Jurnal Tengkawang, 9 (1):1-13.

Swantara, I. M. D. (2014). Aspek dan Teknik Penelitian Senyawa Bahan Alam. Bali: Universitas Udayana.

Thomas, M., Manuntun, M., \& I. A. Raka, Astiti A. (2013). Pemanfaatan Zat Warna Alam dai Ekstrak Kulit Akar Mengkudu (Morinda citrifolia Linn) Pada Kain Katun. Jurnal Kimia, 7 (2):119-126.

Wiraningtyas, A., Ruslan, Sry, Agustina, \& Uswatun, H. (2019). Penentuan Nilai Sun Protection Factor (SPF) dari Ekstrak Kulit Bawang Merah. Jurnal Redoks, 4 (01):3443.

Wiraningtyas, A., Retno, A., Rita, F., Hadijatul, Q., Ana, F., Ruslan, \& Nurfidianty, A. (2019). Ekstraksi Zat Warna dari Rumput Laut Sargassum sp. Menggunakan Pelarut Methanol. Jurnal Redoks, 2(1):1-8. 